\title{
Production of Alkaline Protease Using Industrial Waste Effluent as Low-cost Fermentation Substrate
}

\author{
H. Zare'1, F. Meiguni², G. D. Najafpour²* \\ ${ }^{1}$ Department of Chemical and Materials Engineering, Imam Khomeini International University - Buin Zahra Higher Education Center of \\ Engineering and Technology, Buein Zahra, Qazvin, Iran \\ ${ }^{2}$ Biotechnology Research Laboratory, Faculty of Chemical Engineering, Babol Noshirvani University of Technology, Ba bol, Iran
}

\section{PAPER I NFO}

\section{Paperhistory:}

Received 04 August 2021

Accepted in revised form 13 September 2021

\section{Keywords:}

Alkaline protease

Bacillus sp.

Fermentation

Low-cost substrate

Waste effluent

\section{$A \begin{array}{llllllll}A & S & T & R & A & C & T\end{array}$}

Alkaline proteases are the most important groups of commercial enzymes, which have been broadly used in industrial processes. In this study, Bacillus sp. PTCC 1538 was selected as a biological agent to producealkalineprotease. Enzyme production under submerge fermentation using industrial waste effluent was investigated. Since the costs of the raw material plays an important role in the cost of enzyme production, corn steep liquor (CSL) was selected as a lowcost substrate to reduce the cost of enzyme production. Various carbon sources were used as the auxiliary substrates to enhance enzyme production. Results showed that maximum enzyme activity was obtained when wheat bran was used as an auxiliary substrate. Optimal media composition and growth conditions for alkaline protease production were defined. The optimum conditions were found to be $\mathrm{pH} 8$, incubation temperature of $37^{\circ} \mathrm{C}$, CSL inoculum size of $5 \mathrm{v} / \mathrm{v} \%$, yeast extract and wheat bran concentrations of 2 and $6 \mathrm{~g} / \mathrm{l}$, respectively. $\mathrm{CaCl}_{2}$ was used as an activator to enhance proteolytic activity of the enzyme. Under optimum condition, enzyme activity of $100.7 \mathrm{U} / \mathrm{ml}$ was obtained at $\mathrm{CaCl}_{2}$ concentration of $1.5 \mathrm{~g} / \mathrm{l}$.

doi: $10.5829 /$ ijee.2021.12.03.11

\section{INTRODUCTION}

Proteases represent one of the most important groups of enzymes, which have found a wide application in various industries such as pharmaceutical, detergents, X-ray films, animal feed stocks and food [1-6]. Proteases are classified into alkaline, acidic and neutral proteases according to the optimum $\mathrm{pH}$ of their activities [7-10]. Alkaline proteases are generally used as detergent additives and they represent $60 \%$ of the total worldwide enzymes sales [11, 12]. Alkaline proteases show high enzymatic activity under harsh conditions such as alkaline $\mathrm{pH}$ and high temperature in the presence of various chemical agents [13].

Microbial proteases are the most significant in compare to proteases obtained from plants or animal organs [14-16]. Generally, proteases are commercially produced by microorganis ms that generate a considerable amount of extracellular product. For commercial production of alkaline protease, microbial cells should ensure high yield using low cost methods [17]. Alkaline proteases are derived from a wide range of microorganisms such as yeasts, molds and bacteria. Bacillus species are the most important microorganisms which have been commercially used for the production alkaline proteases [18-20]. Bacillus sp. are generally aerobic and gram positive microorganis ms that grow well in simple media. These species are able to produce hydrolytic enzymes such as glucanase, mannanase and protease using various media $[11,21]$.

Microbial proteases can be produced using submerged and solid-state fermentation processes [22, 23]. It has been reported that about $90 \%$ of the commercial enzymes are produced by the submerged fermentation processes. Submerged method is the best fermentation processes for the bacteria because it ensures

\footnotetext{
*Corresponding Author Email: najafpour8@gmail.com (G. D. Najafpour)
}

Please cite this article as: H. Zare, F. Meiguni, G. D. Najafpour, 2021. Production of Alkaline Protease Using Industrial Waste Effluent as Lowcost Fermentation Substrate, Iranian (Iranica) Journal of Energy and Environment, 12(3), pp. 264-272. Doi: 10.5829/ijee.2021.12.03.11 
high moisture content for bacterial cell growth. The advantages of submerged fermentation processes are consistent enzyme production and simple purification of products [24-26].

The extracellular protease production is significantly affected by process conditions such as incubation time, $\mathrm{pH}$, temperature and inoculum size, and especially media composition [27, 28]. In addition, in submerged fermentation up to $40 \%$ of the cost of enzyme production is due to the media component and substrate [29, 30]; therefore, optimization of the medium composition is essential in microbial protease production [3].

Culture composition significantly affect enzyme production. The source of carbon and nitrogen plays an important role in the production of enzymes. According to the literature, both nature and the concentration of carbon and nitrogen sources are essential nutritional factors that regulate enzyme production; therefore, selecting the appropriate carbon and nitrogen sources in the enzyme production process is critical stage of experimental work [31, 32].

Production of protease from low cost feed stocks or agricultural byproducts as substrate is one of the common method for reducing cost of the production [33]. Low cost sources of carbon and nitrogen play an important role in commercialization of the production processes [34]. Corn steep liquor (CSL) is a byproduct of corn wet-milling. CSL is an important constituent of some growth media. CSL is a source of elemental nutrients such as nitrogen, reducing sugars, minerals, proteins, enzymes, organic acids and vitamins. In the chemical industry, CSL as a low cost substrate is widely used in fermentation processes [35-37].

The aim of this work is to investigate an inexpensive agro-based feed stocks for production of protease under submerged fermentation. CSL, a waste material of corn wet-milling, was selected as a low cost substrate for protease production using Bacillus sp.. Various carbon and nitrogen sources were evaluated to enhance enzyme production. Media composition and growth conditions of Bacillus sp. for alkaline protease production were optimized.

\section{MATERIAL AND METHODS}

\section{Microorganism and culture maintenance}

Bacillus sp. PTCC 1538 was supplied by Iranian Research Organization for Scientific and Technology (IROST). The bacterial strain isolated from soil known as an antifungal and native strain. This microorganism was cultivated in a solution containing (g/l): glucose 4 , yeast extract 2, peptone 2, potassium dihydrogen phos phate 1 , and magnesium sulfate 0.2 . For the solid media preparation, $2 \%$ agar was added to this formulation and stocks were maintained at $4{ }^{\circ} \mathrm{C}$. The prepared seed culture was incubated at $37{ }^{\circ} \mathrm{C}, 110 \mathrm{rpm}$ for duration of $24 \mathrm{~h}$. The culture was regenerated every 2-3 weeks on a fresh plate from the stock culture. Ability of production protease by Bacillus sp. was investigated with cultivation of Bacillus $\mathrm{sp}$. on casein agar plate containing (g/l): peptone 5.0, beef extract 5, $\mathrm{NaCl} 5$, casein 10 and bacteriological agar 12 . The appearance of clear zone showed that Bacillus sp.can produce protease enzyme.

\section{Materials}

In this research the CSL was collected from Glucosan Company (Alborz industrial town, Qazvin). The waste effluent collected from Glucosan Company was characterized. Table 1 summarizes waste effluent characterization. Total solid $7 \%$, choline $5.6 \mathrm{mg} / \mathrm{kg}$, niacin $0.16 \mathrm{mg} / \mathrm{kg}$, histidine $2.8 \%$, isoleucine $3.6 \%$, leucine $4.7 \%$, lysine $2.5 \%$, phenylalanine $4.4 \%$, tyrosine $3.4 \%$ and valine $5.8 \%$. Wheat bran was locally supplied, grinded and used as carbon source. Waste materials were washed with tap water followed by distilled water to remove the adhered surface dust particles. FolinCiocalteu's phenol solution was purchased from SigmaAldrich (USA). All other chemicals were purchased from Merck (Darmstadt, Germany).

\section{Inoculum preparation and protease production}

The inoculum was prepared by adding a loop full of pure culture into $50 \mathrm{ml}$ of sterile medium containing $(\mathrm{g} / \mathrm{l})$ : glucose 4 , yeast extract 2 , peptone $2, \mathrm{KH}_{2} \mathrm{PO}_{4} 1$, $\mathrm{MgSO}_{4} \cdot \mathrm{H}_{2} \mathrm{O} 0.2$ and incubated at $37{ }^{\circ} \mathrm{C}, 130 \mathrm{rpm}$ for 24 h. A $3 \%$ inoculum from the culture was added to medium

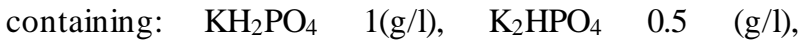
$\mathrm{MgSO}_{4} .7 \mathrm{H}_{2} \mathrm{O} 0.2(\mathrm{~g} / \mathrm{l})$ and CSL $30 \%(\mathrm{w} / \mathrm{w})$. This volume of CSL was determined with preliminary experiments and used as a carbon and nitrogen source. After $72 \mathrm{~h}$ of incubation at $37{ }^{\circ} \mathrm{C}$ under shaking condition (130 rpm), the culture was harvested and protease activity was measured. The media were sterilized by autoclaving at $121{ }^{\circ} \mathrm{C}$ and $15 \mathrm{psig}$ for $20 \mathrm{~min}$.

Table 1. Characterization of the waste effluent collected from Glucosan Company

\begin{tabular}{lc}
\hline Component & Amount \\
\hline Total Solid & $7 \%$ \\
Choline & $5.6 \mathrm{mg} / \mathrm{kg}$ \\
Niacin & $0.16 \mathrm{mg} / \mathrm{kg}$ \\
Histidine & $2.8 \%$ \\
Isoleucine & $3.6 \%$ \\
Leucine & $4.7 \%$ \\
Lysine & $2.5 \%$ \\
Phenylalanine & $4.4 \%$ \\
Tyrosine & $3.4 \%$ \\
Valine & $5.8 \%$ \\
\hline
\end{tabular}




\section{Assay of protease activity}

The protease activity was determined by the method that suggested by Sigma-Aldrich (St. Louis, MO, USA) based on scientific literature $[38,39]$. According to this procedure, $5 \mathrm{ml}$ of $0.65 \%(\mathrm{w} / \mathrm{v})$ casein dissolved in the potassiumphos phate buffer $(\mathrm{pH} 7.5,50 \mathrm{mM})$, then placed in a water bath at $37{ }^{\circ} \mathrm{C}$ for 5 min until equilibrium condition was achieved. In the next step, $1 \mathrm{ml}$ of enzyme solution was added to this mixture and allowed the enzymatic reaction to proceed for $10 \mathrm{~min}$. The reaction was stopped by addition of $5 \mathrm{ml}$ of $110 \mathrm{mM}$ trichloroacetic acid solution. After $30 \mathrm{~min}$ the entire mixture was centrifuged at $8000 \mathrm{rpm}$ for $10 \mathrm{~min}$. Supernatant in the amount of $2 \mathrm{ml}$ was mixed with $5 \mathrm{ml}$ of $500 \mathrm{mM} \mathrm{Na} 2 \mathrm{CO}_{3}$ and $1 \mathrm{ml}$ of Folin-Ciocalteu's phenol solution and then kept at water bath at $37{ }^{\circ} \mathrm{C}$ for $30 \mathrm{~min}$. The optical density of the solutions was determined with respect to the blank samples at $660 \mathrm{~nm}$. One unit of protease activity was defined as the amount of enzyme required to release $1 \mu \mathrm{g}$ of tyrosine per $\mathrm{ml}$ per min under standard assay conditions.

\section{Effect of carbon sources}

Various simple and complex carbon sources including glucose, fructose, lactose, starch, wheat bran, grain of wheat and bagasse were used as a supplement source of carbon $(5 \mathrm{~g} / \mathrm{l})$. The enzyme activity was monitored after $96 \mathrm{~h}$ incubation at $37^{\circ} \mathrm{C}$ in an incubator-shakeroperating at $130 \mathrm{rpm}$.

\section{Effect of nitrogen sources}

Organic nitrogen sources including yeast extract, peptone and casein; and inorganic nitrogen sources such as ammonium chloride, ammonium nitrate, sodium nitrate and potassiumnitrate were used. The respective nitrogen sources were added in the production medium $(2 \mathrm{~g} / \mathrm{l})$. The enzyme activity was monitored after $96 \mathrm{~h}$ incubation at $37{ }^{\circ} \mathrm{C}$, under shaking conditions of $130 \mathrm{rpm}$.

\section{Effect of physical parameters}

Effect of various physical parameters such as incubation time $(24,48,72$ and $96 \mathrm{~h})$, initial $\mathrm{pH}(5,6,7,8,9,10,11$ and 12$)$, inoculum size $(2,3,5$ and $10 \%$, v/v), temperature $\left(30,33,37,40\right.$ and $\left.45^{\circ} \mathrm{C}\right)$ and agitation speed (110, 130, 150, 180 and $200 \mathrm{rpm}$ ) under conventional methods for maximum enzyme productions were investigated. All of the experiments were conducted in duplicates.

\section{Effect of $\mathrm{CaCl}_{2}$}

The effect of salt on protease secretion by variation of $\mathrm{CaCl}_{2}$ concentrations $(0.5-2 \mathrm{~g} / \mathrm{l})$ at constant $\mathrm{pH}$ of 8 in production medium was investigated. Enzyme activity was quantified after incubation for $72 \mathrm{~h}$ at $37{ }^{\circ} \mathrm{C}$ under shaking at $150 \mathrm{rpm}$.

\section{Growth kinetics and protease production}

In order to study growth kinetics of microorganism, the inoculum was introduced to optimized and regular media. Samples were aseptically taken and cell density was measured at $600 \mathrm{~nm}$. Also, the enzyme activity of samples was determined.

\section{RESULTS AND DISCUSSION}

\section{Effect of additional carbon sources}

Several carbon sources such as glucose, fructose, lactose, starch, wheat bran, grain of wheat and bagasse were supplemented to culture medium at $5 \mathrm{~g} / \mathrm{l}$ level. Table 2 shows the effect of various carbon sources on enzyme production. Bacillus sp. produced a high level of protease in the presence of complex organic carbon sources. The maximum levels of proteolytic activities were obtained for starch and wheat bran (47.54 and $46.43 \mathrm{U} / \mathrm{ml}$ respectively). The scope of present study was to identify desired composition of low cost media. Wheat bran, which is agro-industrial waste, was preferred over starch due to its high cost. Similar results were obtained by Meena et al. [15]. Simple carbon sources like fructose, lactose and glucose resulted in low activity protease production, 21.49, 31.22 and $27.20 \mathrm{U} / \mathrm{ml}$, respectively. The obtained results in this work were consistent with the literature as complex carbon sources are much better than simple carbon sources [3, 24, 40, 41].

In order to define optimum concentration of carbon source enzyme production was investigated by supplementation of several wheat bran concentrations (2$10 \mathrm{~g} / \mathrm{l})$. Maximum production $(50.81 \mathrm{U} / \mathrm{ml})$ was obtained with $6 \mathrm{~g} / 1$ wheat bran concentration. Further increase in this carbon source adversely affected protease production by Bacillus sp. It appears that the high sugar content in production medium due to waste had an inhibitory effect on the protease production.

Table 2. Effect of additional carbon sources on protease production in basal medium

\begin{tabular}{lcc}
\hline Carbon sources & Concentration $(\mathbf{g} / \mathbf{l})$ & Protease activity $(\mathbf{U} / \mathbf{m l})$ \\
\hline Glucose & 5 & 27.2 \\
Fructose & 5 & 21.49 \\
Lactose & 5 & 31.22 \\
Starch & 5 & 47.54 \\
Grain of wheat & 5 & 39.15 \\
Bagasse & 5 & 37.63 \\
Wheat bran & 2 & 34.78 \\
Wheat bran & 4 & 42.765 \\
Wheat bran & 5 & 46.43 \\
Wheat bran & 6 & 50.81 \\
Wheat bran & 8 & 48.59 \\
Wheat bran & 10 & 41.71 \\
\hline
\end{tabular}




\section{Effect of nitrogen supplementation}

Alkaline protease production is significantly dependent on the nitrogen sources available in the medium. Nitrogen is an essential element which participates in the structure of proteins, nucleic acids, amino acids and other cell components of microorganisms $[9,17,41]$. The nitrogen sources also function as inducers of enzyme production [41]. The organic nitrogen sources used in our study supported protease production, while the maximu m effect on production was achieved with yeast extract (Table 3 ). The effect of yeast extract on the enzyme production was further investigated at different concentrations (1-5 g/l). Maximum production was obtained with $2 \mathrm{~g} / \mathrm{l}$ of yeast extract. Furthermore, inorganic nitrogen sources proved less favorable towards enzyme secretion. There are several reports on the repressive role of organic nitrogen sources, for instance excessive amino acid and ammonium ions in alkaline protease production [42-44].

Fermentation was carried out with optimized conditions to investigate the effect of carbon and nitrogen sources on the alkaline protease production by Bacillus strain. As shown in Figure 1, protease production increased with increasing incubation time from 24 to 72 $\mathrm{h}$ and then decreased at $96 \mathrm{~h}$. At incubation time of $72 \mathrm{~h}$, the protease production was more than $75.75 \mathrm{U} / \mathrm{ml}$ and three-fold increase in protease activity was observed. The time required for maximum protease production depends on the nature of microorganism, medium composition and cultural conditions of fermentation process. An increase in incubation time resulted in an increase in protease secretion and consequently the yield of protease production increases. The decrease in enzyme yield after the optimum incubation time might be explained because of auto-degradation of proteases, catabolic repression, cell growth inhibition and also because of nutrient depletion.

Table 3. Effect of nitrogen supplementation on protease production in basal medium containing $6 \mathrm{~g} / \mathrm{l}$ wheat bran

\begin{tabular}{lll}
\hline $\begin{array}{l}\text { Nitrogen } \\
\text { supplementation }\end{array}$ & $\begin{array}{l}\text { Concentration } \\
(\mathbf{g} / \mathbf{l})\end{array}$ & $\begin{array}{l}\text { Protease } \\
\text { acti vity }(\mathbf{U} / \mathbf{m l})\end{array}$ \\
\hline Peptone & 2 & 62.52 \\
Casein & 2 & 54.42 \\
Ammonium chloride & 2 & 37.22 \\
Sodium nitrate & 2 & 42.76 \\
Potassium nitrate & 2 & 44.22 \\
Yeast extract & 1 & 70.56 \\
Yeast extract & 2 & 75.75 \\
Yeast extract & 3 & 43.05 \\
Yeast extract & 4 & 38.56 \\
Yeast extract & 5 & 18.38 \\
\hline
\end{tabular}

\section{Effect of pH}

Culture $\mathrm{pH}$ is one of the key parameters affecting alkaline protease production by microorganisms. In fermentation process, many biochemical and enzymatic reactions, and also components transfer through the cell membranes intensely depends on the extracellular $\mathrm{pH}$. As shown in Figure 2, high enzyme activity was observed at alkaline $\mathrm{pH}$ ranges from 7 to 9 . Maximum enzyme production $(77.56 \mathrm{U} / \mathrm{ml}$ ) was obtained at $\mathrm{pH}$ of 8 (Figure 2).

\section{Effect of inoculum size}

The optimization of inoculum cell density is quite important, as high inoculum density can reduce lag phase and increase enzyme production due to competition for the availability of nutrients. In a similar manner, low cell density can result in a mitigation of enzyme secretion, owing to a drop in cell populations [45]. Inoculum size for this study was selected according to literature in the range of 2 to $10 \%$ [46-49]. It is apparent that protease production increased steadily with increasing the inoculum size, until a magnitude was reached at which

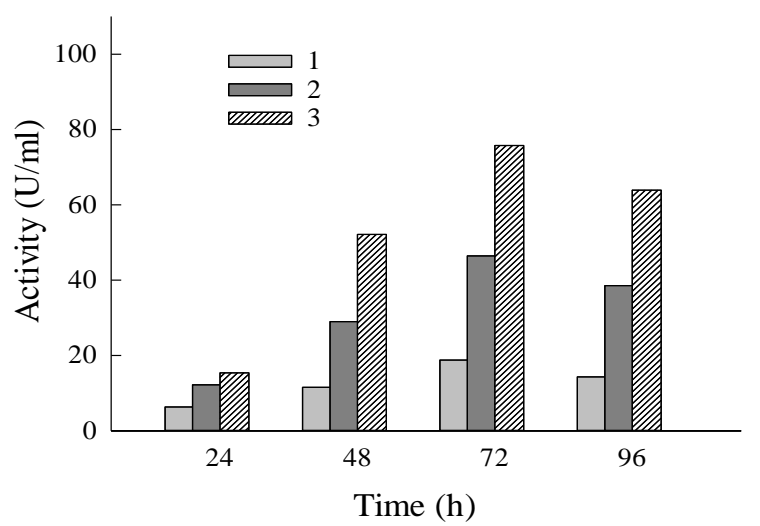

Figure 1. Production of alkaline protease from Bacillus sp. in initial medium (1), initial medium + wheat bran (2), initial medium + wheat bran + yeast extract $(3)$

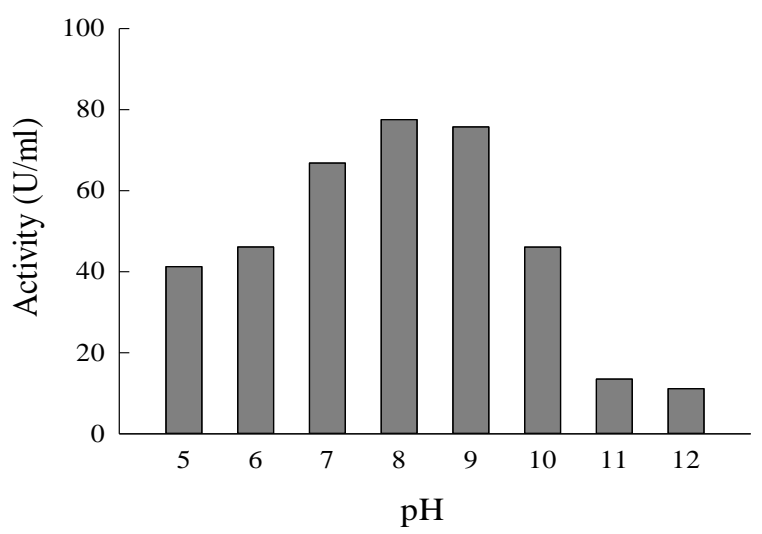

Figure 2. Effect of initial $\mathrm{pH}$ of medium on protease production 
enzyme productivity achieved maximum levels (inoculum size of 5\%, v/v) (Figure 3); this concentration became probably a threshold changing the pathways of cell growth towards enzyme synthesis. Inoculation with inoculum size of $10 \%$ may increases the old and inactive cells in the production medium and causes the protease production to decrease. In addition, low inoculum sizes of 2 and $3 \%$ causes long lag phase of microbial growth which leads to decrease in enzyme productivities.

\section{Effect of incubation temperature}

In Fermentation process, the cell growth rate and metabolic activities of the microorganism are highly dependent on the incubation temperature. The effect of temperature $\left(30\right.$ to $45{ }^{\circ} \mathrm{C}$ ) on the production of protease was investigated.

The optimum temperature of incubation was found to be $37{ }^{\circ} \mathrm{C}$ that resulted in protease production of $90.1 \mathrm{U} / \mathrm{ml}$ (Figure 4). A comparis on of the alkaline Bacillus strains producing alkaline proteases revealed that most of the alkaline Bacillus strains were of mesophilic type with optimum temperature range of $30-37{ }^{\circ} \mathrm{C}[8,11,13]$.

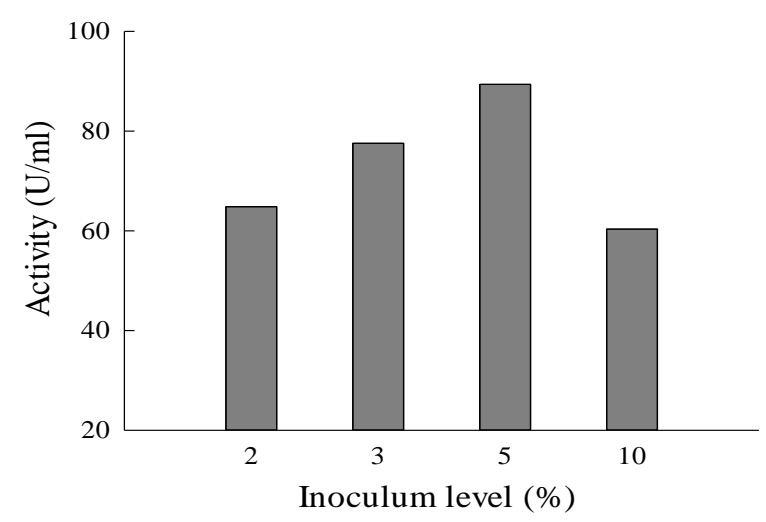

Figure 3. Effect of inoculum level on protease production

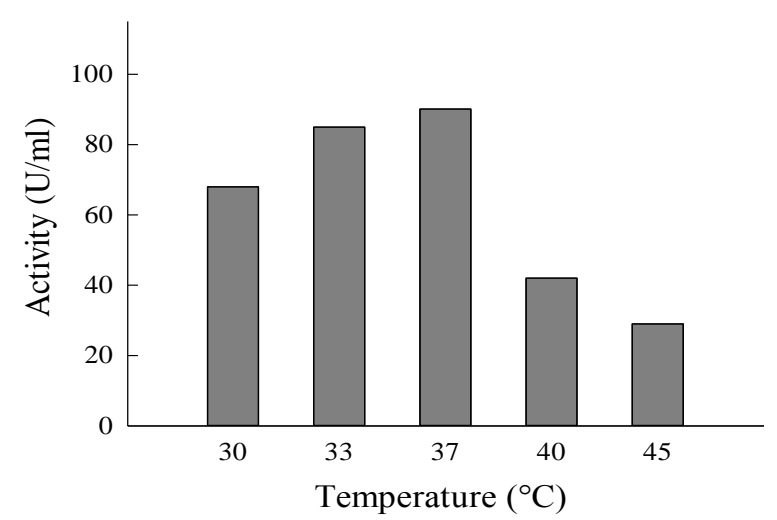

Figure 4. Effect of incubation temperature on protease production

\section{Effect of $\mathrm{CaCl}_{2}$ concentration}

In order to stabilize the protease secreted by Bacillus sp., $\mathrm{CaCl}_{2}$ was used in the fermentation media. $\mathrm{CaCl}_{2}$ also maintain the molecular conformation and enhances the enzyme activity. Figure 5 shows the effect of $\mathrm{CaCl}_{2}$ concentration on protease production. The positive effect of $\mathrm{CaCl}_{2}$ at $1.5 \mathrm{~g} / 1$ concentration was pronounced with respect to specific protease activities. The higher concentration of $\mathrm{CaCl}_{2}(2 \mathrm{~g} / \mathrm{l})$ had an inhibitory effect on enzyme production and decreased the enzyme activity to $65.26 \mathrm{U} / \mathrm{ml}$.

\section{Activity and stability of alkaline protease}

The effect of different $\mathrm{pH}$ values (7-13) on the activity of produced protease was studied. The relative activity (\%) was calculated as the ratio of the enzyme activity to the maximum activity. Protease from Bacillus sp. PTCC 1538 showed proper enzymatic activity at $\mathrm{pH}$ lower than 11. Maximum protease activity was obtained at $\mathrm{pH} 8$ (Figure 6a). Alkaline protease retained $82 \%$ of its activity at $\mathrm{pH} 11$. The effect of temperature from 30 to $70{ }^{\circ} \mathrm{C}$ on the protease activity was investigated at $\mathrm{pH} 8$. As shown in Figure $6 \mathrm{~b}$ maximum protease activity was achieved at $50{ }^{\circ} \mathrm{C}$.

The thermal stability of the protease produced with and without $\mathrm{CaCl}_{2}$ was determined at $\mathrm{pH} 8$ and different temperatures from 30 to $60{ }^{\circ} \mathrm{C}$ for $30 \mathrm{~min}$. Results indicate that $\mathrm{CaCl}_{2}$ Enhanced the thermal stability of alkaline protease (Figure 7).

\section{Growth study and protease production}

The growth kinetics of Bacillus sp. for production of alkaline protease under unoptimized and optimized conditions were investigated. Figure 8 represents protease activity and cell dry weight of Bacillus sp. with respect to the incubation time. Medium compositions and cultural conditions of the optimized and unoptimized were $\mathrm{KH}_{2} \mathrm{PO}_{4} \quad 1 \mathrm{~g} / \mathrm{l}, \mathrm{K}_{2} \mathrm{HPO}_{4} 0.5 \mathrm{~g} / \mathrm{l}, \mathrm{MgSO}_{4} .7 \mathrm{H}_{2} \mathrm{O} 0.2 \mathrm{~g} / \mathrm{l}$, waste $30 \%(\mathrm{w} / \mathrm{w})$, wheat bran $6 \mathrm{~g} / \mathrm{l}$, yeast extract $2 \mathrm{~g} / \mathrm{l}$,

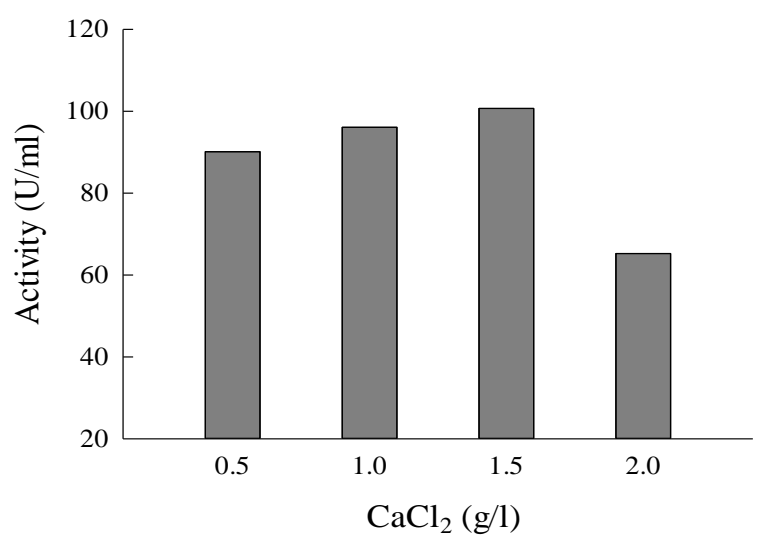

Figure 5. Effect of $\mathrm{CaCl}_{2}$ concentration on protease production 
$\mathrm{CaCl}_{2} 1.5 \mathrm{~g} / \mathrm{l}$, initial $\mathrm{pH}$ of $8,37{ }^{\circ} \mathrm{C}$ and $150 \mathrm{rpm}$, and $\mathrm{KH}_{2} \mathrm{PO}_{4} 1 \mathrm{~g} / \mathrm{l}, \mathrm{K}_{2} \mathrm{HPO}_{4} 0.5 \mathrm{~g} / \mathrm{l}, \mathrm{MgSO}_{4} .7 \mathrm{H}_{2} \mathrm{O} \quad 0.2 \mathrm{~g} / \mathrm{l}$, waste $30 \%(\mathrm{w} / \mathrm{w})$, initial $\mathrm{pH}$ of $7,37^{\circ} \mathrm{C}$ and $130 \mathrm{rpm}$, respectively. For optimized condition protease activitywas sharply increased during the exponential growth phase and then the activity reached to $100.7 \mathrm{U} / \mathrm{ml}$ after $72 \mathrm{~h}$.
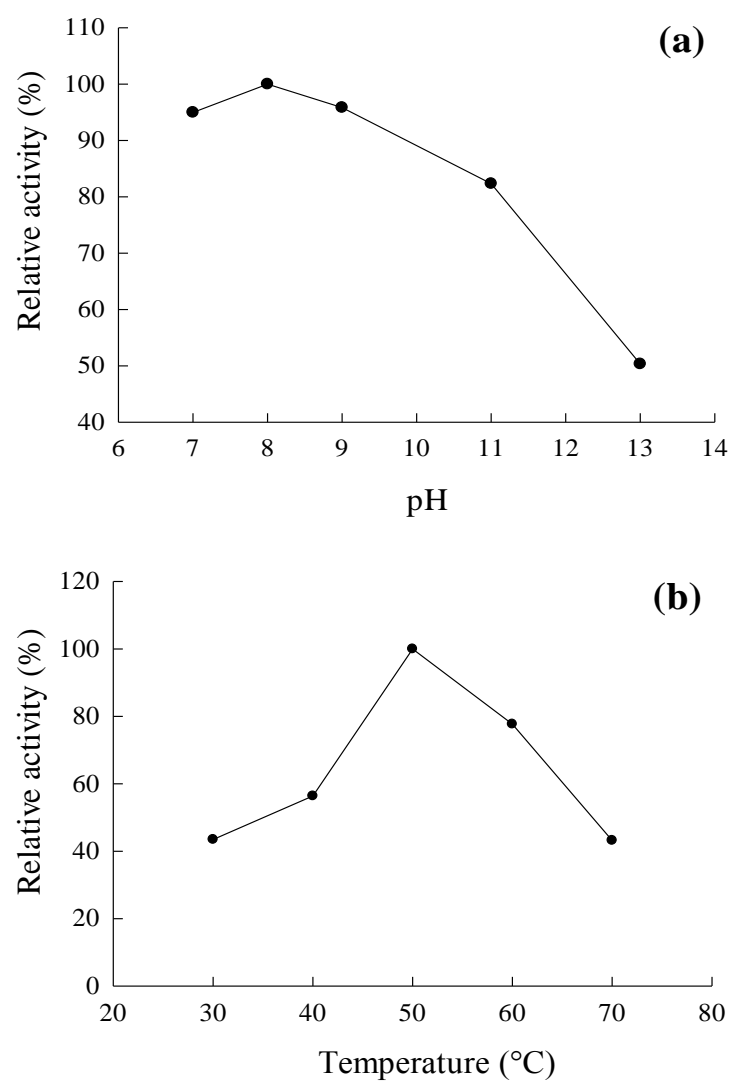

Figure 6. Effect of pH (a) and temperature (b) on alkaline protease activity

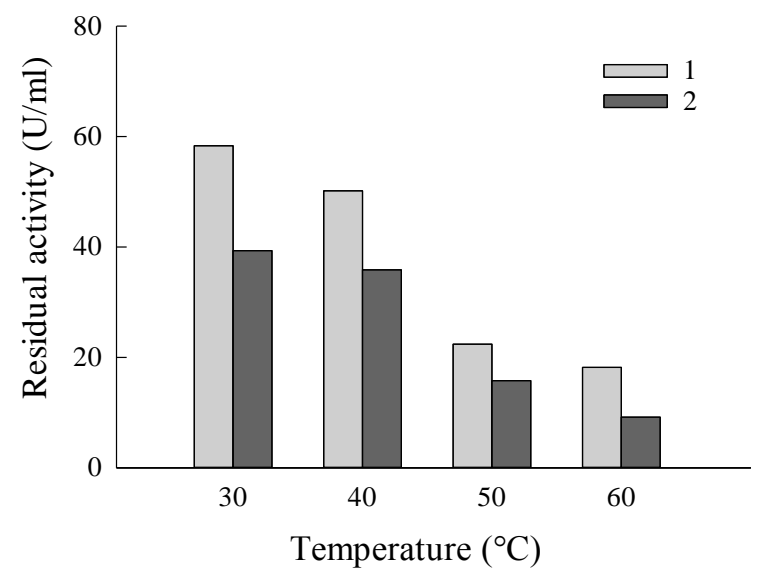

Figure 7. Thermal stability of alkaline protease in the presence (1) and absence (2) of $\mathrm{CaCl}_{2}$

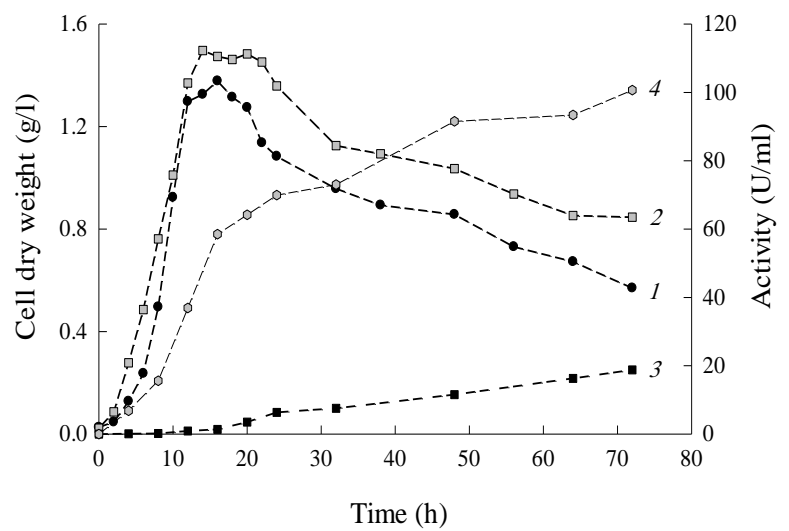

Figure 8. Growth of Bacillus sp. in initial (1) and optimized (2) medium, and protease production in initial (3) and optimized (4) medium

\section{CONCLUSION}

Due to an increase in feedstock costs for production of alkaline protease enzymes, this work was carried out to optimize a variety of fermentation parameters, including medium compositions and incubation conditions, for maximum alkaline protease production. The optimal medium composition and cultural conditions for highly extracellular alkaline protease production were $\mathrm{KH}_{2} \mathrm{PO}_{4}$ $1 \mathrm{~g} / \mathrm{l}, \mathrm{K}_{2} \mathrm{HPO}_{4} 0.5 \mathrm{~g} / \mathrm{l}, \mathrm{MgSO}_{4} .7 \mathrm{H}_{2} \mathrm{O} 0.2 \mathrm{~g} / \mathrm{l}$, waste $30 \%$ (w/w), wheat bran $6 \mathrm{~g} / \mathrm{l}$, yeast extract $2 \mathrm{~g} / \mathrm{l}, \mathrm{CaCl}_{2} 1.5 \mathrm{~g} / \mathrm{l}$ and initial $\mathrm{pH}$ of 8 , respectively. Selected operating parameters for extracellular production were incubation temperature of $37{ }^{\circ} \mathrm{C}$ and agitation rate at $150 \mathrm{rpm}$. Results showed that addition of $\mathrm{CaCl}_{2}$ as an activator significantly enhanced enzymatic activity and thermal stability of alkaline protease.

\section{ACKNOWLEDGEMENT}

The authors wish to acknowledge Biotechnology Research Laboratory, Noshirvani University of Technology, Babol, Iran for the support and facilities provided to accomplish the present research work.

\section{REFERENCES}

1. El-Khonezy, M. I., Elgammal, E. W., Ahmed, E. F. and AbdElaziz, A. M., 2021. "Detergent Stable T hiol-Dependant Alkaline Protease Produced from the Endophytic Fungus Aspergillus ochraceus Bt 21: Purification and Kinetics", Biocatalysis and Agricultural Biotechnology, https://doi.org/10.1016/j.bcab.2021.102046.

2. Srividya, S. and Mala, M., 2011. "Influence of process parameters on the production of detergent compatible alkaline protease by a newly isolated Bacillus sp. Y.”, Turkish Journal of Biology, 35(2), pp: 177-182, https://doi.org/10.1016/j.wasman.2020.02.043. 
3. Haddar, A., Fakhfakh-Zouari, N., Hmidet, N., Frikha, F., Nasti, M. and Kamoun, A. S., 2010. "Low-cost fermentation medium for alkaline protease production by Bacillus mojavensis A21 using hulled grain of wheat and sardinella peptone", Journal of Bioscience and Bioengineering, 110(3), pp: 288-294, https://doi.org/10.1016/j.jbiosc.2010.03.015.

4. Cao, S., Song, J., Li, H., Wang, K., Li, Y., Li, Y., Lu, F. and Liu, B., 2020. "Improving characteristics of biochar produced from collagen-containing solid wastes based on protease application in leather production", Waste Management, 105, pp: 531-539, https://doi.org/10.1016/j.wasman.2020.02.043.

5. Dorra, G., Ines, K., Imen, B. S., Laurent, C., Sana, A., Olfa, T., Pascal, C., Thierry, J. and Ferid, L., 2018. "Purification and characterization of a novel high molecular weight alkaline protease produced by an endophytic Bacillus halotolerans strain CT 2", International Journal of Biological Macromolecules, 111, pp: 342-351, https://doi.org/10.1016/j.ijbiomac.2018.01.024.

6. Marathe, S. K., Vashistht, M. A., Prashanth, A., Parveen, N., Chakraborty, S. and Nair, S. S., 2018. "Isolation, partial purification, biochemical characterization and detergent compatibility of alkaline protease produced by Bacillus subtilis, Alcaligenes faecalis and Pseudomonas aeruginosa obtained from sea water samples", Journal of Genetic Engineering and Biotechnology, 16(1), pp: 39-46, https://doi.org/10.1016/j.jgeb.2017.10.001.

7. Osmolovskiy, A., Kreier, V., Baranova, N. and Egorov, N., 2017. "Properties of extracellular plasmin-like proteases of Aspergillus ochraceus micromycete", Applied Biochemistry and Microbiology, 53(4), pp: 429-434, https://doi.org/10.1134/S000368381704010X.

8. Rai, S. K. and Mukherjee, A. K., 2010. "Statistical optimization of production, purification and industrial application of a laundry detergent and organic solvent-stable subtilisin-like serine protease (Alzwiprase) from Bacillus subtilis DM-04", Biochemical Engineering Journal, 48(2), pp: 173-180, https://doi.org/10.1016/j.bej.2009.09.007.

9. Raj, A., Khess, N., Pujari, N., Bhattacharya, S., Das, A. and Rajan, S. S., 2012. "Enhancement of protease production by Pseudomonas aeruginosa isolated from dairy effluent sludge and determination of its fibrinolytic potential", Asian Pacific Joumal of Tropical Biomedicine, 2(3), pp: S1845-S1851, https://doi.org/10.1016/S2221-1691(12)60506-1.

10. Mehmet, N., Diken, G., Yazici, M., Mazlum, Y., Sayin, S. and Söyler, O., 2021. "The changes in Alkaline, Neutral and Acid Protease Activities of ArtemiaEnriched with Commercial Emulsion and Different Additive Combinations", Aquatic Sciences and Engineering, 36(3), pp: 152-158, https://doi.org/10.26650/ASE2020793132.

11. Mukherjee, A. K., Adhikari, H. and Rai, S. K., 2008. "Production of alkaline protease by a thermophilic Bacillus subtilis under solidst ate fermentation (SSF) condition using Imperata cylindrica grass and potato peel as low-cost medium: Characterization and application of enzyme in detergent formulation", Biochemical Engineering Journal, 39(2), pp: 353-361, https://doi.org/10.1016/j.bej.2007.09.017.

12. Rajkumar, R., Jayappriyan, K. R. and Rengasamy, R., 2011. "Purification and characterization of a protease produced by Bacillus megaterium RRM2: application in detergent and dehairing industries", Journal of Basic Microbiology, 51(6), pp: 614-624, https://doi.org/10.1002/jobm.201000517.

13. Abidi, F., Limam, F. and Nejib, M. M., 2008. "Production of alkaline proteases by Botrytis cinerea using economic raw materials: assay as biodetergent", Process Biochemistry, 43(11), pp: 1202-1208, https://doi.org/10.1016/j.procbio.2008.06.018.

14. Liang, T.-W., Hsieh, J.-L. and Wang, S.-L., 2012."Production and purification of a protease, a chitosanase, and chitin oligosaccharides by Bacillus cereus TKU022 fermentation",
Carbohydrate Research, 362, pp: $38-46$, https://doi.org/10.1016/j.carres.2012.08.004.

15. Meena, P., Tripathi, A. D., Srivastava, S. and Jha, A., 2013. "Utilization of agro-industrial waste (wheat bran) for alkaline protease production by Pseudomonas aeruginosa in SSF using Taguchi (DOE) methodology", Biocatalysis and Agricultural Biotechnology, 2(3), pp: 210-216, https://doi.org/10.1016/j.bcab.2013.05.003.

16. Shankar, S., Rao, M. and Laxman, R. S., 2011. "Purification and characterization of an alkaline protease by a new strain of Beauveria sp.", Process Biochemistry, 46(2), pp: 579-585, https://doi.org/10.1016/j.procbio.2010.10.013.

17. Patel, R., Dodia, M. and Singh, S. P.,2005. "Extracellular alkaline protease from a newly isolated haloalkaliphilic Bacillus sp.: Production and optimization", Process Biochemistry, 40(11), pp: 3569-3575, https://doi.org/10.1016/j.procbio.2005.03.049.

18. Ahmed, E., Rateb, M., El-Kassem, L. A. and Hawas, U. W., 2017. "Anti-HCV protease of diketopiperazines produced by the Red Sea sponge-associated fungus Aspergillus versicolor", Applied Biochemistry and Microbiology, 53(1), pp: 101-106, https://doi.org/10.1134/S0003683817010021.

19. Pouryafar, F., Najafpour, G., Noshadi, N. and Jahanshahi, M., 2015. "Thermostable alkaline protease production via solid state fermentation in a tray bioreactor using Bacillus licheniformis ATCC 21424", International Journal of Environmental Research, 9(4), pp: 1127-1134,https://doi.org/10.22059/ijer.2015.1001.

20. Devanadera, M. K. P., Haw, S. V. O., Arzaga, M. J. J., Buenaflor, L. J., Gagarin, T. J. E., Vargas, A. G., Mercado, S. M. and Santiago, L. A., 2021. "Optimization, production, partial purification and characterization of neutral and alkaline proteases produced by Bacillus subtilis", Journal of Microbiology, Biotechnology and Food Sciences, 2021, ,pp: 832-838, https://doi.org/10.15414/jmbfs.2016.6.2.832-838.

21. Noshadi, N., Mohammadi, M., Najafpour, G. and Pouryafar, F., 2017. "Thermostable alpha-amylase from Lignocellulosic Residues Using Bacillus amyloliquefaciens", International Journal of Engineering, Transactions B: Applications, 30(8), pp: 1110-1117, https://doi.org/10.5829/ije.2017.30.08b.01

22. Mahmoodi, M., Najafpour, G. and Mohammadi, M., 2017. "Production of pectinases for quality apple juice through fermentation of orange pomace", Journal of Food Science and Technology, 54(12), pp: 4123-4128, https://doi.org/10.1007/s13197-017-2829-8.

23. Elumalai, P., Lim, J.-M., Park, Y.-J., Cho, M., Shea, P. J. and Oh, B.-T., 2020. "Agricultural waste materials enhance protease production by Bacillus subtilis B22 in submerged fermentation under blue light-emitting diodes", Bioprocess and Biosystems Engineering, pp: 1-10, https://doi.org/10.1007/s00449-01902277-5.

24. Oskouie, S. F. G., Tabandeh, F., Yakhchali, B. and Eftekhar, F., 2008. "Response surface optimization of medium composition for alkaline protease production by Bacillus clausii", Biochemical Engineering Journal, 39(1), pp: 37-42, https://doi.org/10.1016/j.bej.2007.08.016.

25. Rajan, A. and Nair, A. J., 2011. "A comparative study on alkaline lipase production by a newly isolated Aspergillus fumigatus MTCC 9657 in submerged and solid-state fermentation using economically and industrially feasible substrate", Turkish Joumal of Biology, 35(5), pp: 569-574, https://doi.org/10.3906/biy-09126.

26. Birhanli, E. and Yeşilada, Ö., 2013. "The utilization of lignocellulosic wastes for laccase production under semisolidstate and submerged fermentation conditions", Turkish Joumal of Biology, 37(4),pp: 450-456, https://doi.org/10.3906/biy-1211-25.

27. da Silva, O. S., de Almeida, E. M., de Melo, A. H. F. and Porto, T. S., 2018. "Purification and characterization of a novel extracellular serine-protease with collagenolytic activity from Aspergillus 
tamarii URM4634", International Journal of Biological Macromolecules, https://doi.org/10.1016/j.ijbiomac.2018.06.002.

28. Watanabe, M., Techapun, C., Kuntiya, A., Leksawasdi, N Seesuriyachan, P., Chaiyaso, T., Takenaka, S., Maeda, I., Koyama, M. and Nakamura, K., 2017. "Extracellular protease derived from lactic acid bacteria stimulates the fermentative lactic acid production from the by-products of rice as a biomass refinery function", Journal of Bioscience and Bioengineering, 123(2), pp: 245-251, https://doi.org/10.1016/j.jbiosc.2016.08.011.

29. El Enshasy, H., Abuoul-Enein, A., Helmy, S. and El Azaly, Y., 2008. "Optimization of the industrial production of alkaline protease by Bacillus licheniformis in different production scales", Aust. J. Basic Appl. Sci, 2(3), pp: 583-593.

30. Joo, H.-S. and Chang, C.-S., 2006. "Production of an oxidant and SDS-stable alkaline protease from an alkaophilic Bacillus clausii I-52 by submerged fermentation: Feasibility as a laundry detergent additive", Enzyme and Microbial Technology, 38(1), pp: 176-183, https://doi.org/10.1016/j.enzmictec.2005.05.008.

31. Juhasz, T., Szengyel, Z., Reczey, K., Siika-Aho, M. and Viikari, L., 2005. "Characterization of cellulases and hemicellulases produced by Trichoderma reesei on various carbon sources", Process Biochemistry, 40(11), pp: 3519-3525, https://doi.org/10.1016/j.procbio.2005.03.057.

32. Mikiashvili, N., Wasser, S. P., Nevo, E. and Elisashvili, V., 2006. "Effects of carbon and nitrogen sources on Pleurotus ostreatus ligninolyt ic enzyme activity", World Journal of Microbiology and Biotechnology, 22(9), pp: 999-1002, https://doi.org/10.1007/s1 1274-006-9132-6.

33. Hammami, A., Bayoudh, A., Abdelhedi, O. and Nasri, M., 2018. "Low-cost culture medium for the production of proteases by Bacillus mojavensis SA and their potential use for the preparation of antioxidant protein hydrolysate from meat sausage byproducts", Annals of Microbiology, pp: 1-12, https://doi.org/10.1007/s13213-018-1352-0.

34. Qureshi, A. S., Khushk, I., Ali, C. H., Chisti, Y., Ahmad, A. and Majeed, H., 2016. "Coproduction of protease and amylase by thermophilic Bacillus sp. BBXS-2 using open solid-state fermentation of lignocellulosic biomass", Biocatalysis and Agricultural Biotechnology, 8, pp: 146-151, https://doi.org/10.1016/j.bcab.2016.09.006.

35. Obayori, O. S., Adebusoye, S. A., Ilori, M. O., Oyetibo, G. O., Omotayo, A. E. and Amund, O. O., 2010. "Effects of com steep liquor on growth rate and pyrene degradation by Pseudomonas strains", Current Microbiology, 60(6), pp: 407-411, https://doi.org/10.1007/s00284-009-9557-X.

36. Shahzad, F., Abdullah, M., Chaudhry, A. S., Hashmi, A. S., Bhatti, J. A., Jabbar, M. A., Ali, H. M., Rehman, T., Ali, F. and Sattar, M. M. K., 2017. "Addition of molasses, corn steep liquor, and rice polish as economical sources to enhance the fungal biomass production of wheat straw by Arachniotus sp", Turkish Joumal of Veterinary and Animal Sciences, 41(3), pp: 332-336, https://doi.org/10.3906/vet-1610-22.

37. Ramos, P. R., Kamimura, E. S., Pires, N. A. M., Maldonado, R. R and de Oliveira, A. L., 2021. "Esterification reaction in $\mathrm{SC}-\mathrm{CO}_{2}$ catalyzed by lipase produced with corn steep liquor and Minas Frescal cheese whey", Bioresource Technology Reports, 14pp: 100670, https://doi.org/10.1016/j.biteb.2021.100670.
38. Anson, M. L., 1938. "The estimation of pep sin, trypsin, papain, and cathep sin with hemoglobin", Journal of General Physiology, 22(1), pp: 79-89.

39. Folin, O. and Ciocalteu, V., 1927. "On tyrosine and tryptophane determinations in proteins", Journal of Biological Chemistry, 73(2), pp: 627-650, https://developmentalbiology.wustl.edu/upcontent/uploads/2018/10/Folin_1927-2553row.pdf

40. Shivanand, P. and Jayaraman, G., 2009. "Production of extracellular protease from halotolerant bacterium, Bacillus aquimaris strain VITP4 isolated from Kumta coast”, Process Biochemistry, 44(10), pp: 1088-1094, https://doi.org/10.1016/j.procbio.2009.05.010.

41. Wang, S.-L. and Yeh, P.-Y.,2006. "Production of a surfactant-and solvent-stable alkaliphilic protease by bioconversion of shrimp shell wastes fermented by Bacillus subtilis TKU007', Process Biochemistry, 41(7), pp: 1545-1552, https://doi.org/10.1016/j.procbio.2006.02.018.

42. Chauhan, B. and Gupta, R., 2004. "Application of statistical experimental design for optimization of alkaline protease production from Bacillus sp. RGR-14", Process Biochemistry, 39(12),
pp:
$2115-2122$ https://doi.org/10.1016/j.procbio.2003.11.002.

43. Gupta, R., Beg, Q., Khan, S. and Chauhan, B., 2002. “An overview on fermentation, downstream processing and properties of microbial alkaline proteases", Applied Microbiology and Biotechnology, 60(4), 1 pp: https://doi.org/10.1007/s00253-002-1142-1.

44. Kumar, C. G. and T akagi, H., 1999. "Microbial alkaline proteases: from a bioindustrial viewpoint", Biotechnology Advances, 17(7), pp: 561-594, https://doi.org/10.1016/S0734-9750(99)00027-0.

45. Prakasham, R. S., Rao, C. S. and Sarma, P. N., 2006. "Green gram husk - an inexpensive substrate for alkaline protease production by Bacillus sp. in solid-state fermentation", Bioresource Technology, 97(13), pp: 1449-1454, https://doi.org/10.1016/j.biortech.2005.07.015.

46. Beg, Q. K., Sahai, V. and Gupta, R., 2003. "Statistical media optimization and alkaline protease production from Bacillus mojavensis in a bioreactor", Process Biochemistry, 39(2), pp: 203 209, https://doi.org/10.1016/S0032-9592(03)00064-5.

47. Hakim, A., Bhuiyan, F. R., Iqbal, A., Emon, T. H., Ahmed, J. and Azad, A. K., 2018. "Production and partial characterization of dehairing alkaline protease from Bacillus subtilis AKAL7 and Exiguobacterium indicum AKAL11 by using organic municipal solid wastes", Heliyon, 4(6), pp: e00646, https://doi.org/10.1016/j.heliyon.2018.e00646.

48. Hussain, F., Kamal, S., Rehman, S., Azeem, M., Bibi, I., Ahmed, T. and Iqbal, H. M., 2017. "Alkaline protease production using response surface methodology, characterization and industrial exploitation of alkaline protease of Bacillus subtilis sp", Catalysis Letters, 147(5), pp: 1204-1213, https://doi.org/10.1007/s10562017-2017-5.

49. Ramkumar, A., Sivakumar, N., Gujarathi, A. M. and Victor, R. 2018. "Production of thermotolerant, detergent stable alkaline protease using the gut waste of Sardinella longiceps as a substrate: Optimization and characterization", Scientific Reports, 8(1), pp: 115, https://doi.org/10.1038/s41598-018-30155-9.

\section{COPYRIGHTS}

(C2021 The author(s). This is an open access article distributed under the terms of the Creative Commons Attribution (CC BY 4.0), which permits unrestricted use, distribution, and reproduction in any medium, as long as the original authors and source are cited. No permission is required from the authors or the publishers. 


\section{Persian Abstract}

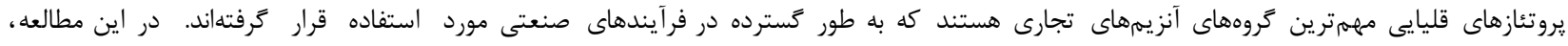
Bacillus sp. PTCC 1538

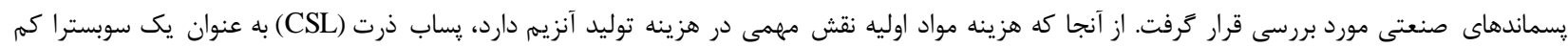

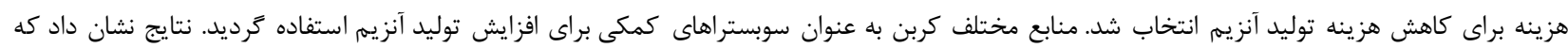

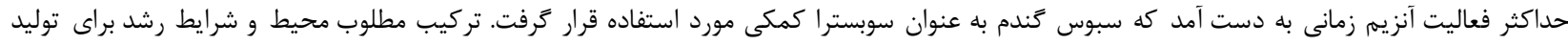

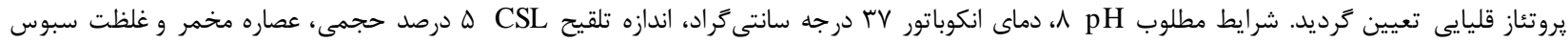

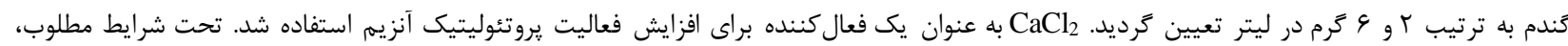

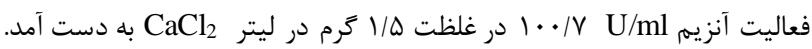

